\title{
Comment on "Multipotency and secretome: the mechanisms behind the regenerative potential of adipose-derived stem cells"
}

\author{
Young-Joon Jun \\ Department of Plastic and Reconstructive Surgery, The Catholic University of Korea, Bucheon 14647, South Korea.
}

Correspondence to: Dr. Young-Joon Jun, Department of Plastic and Reconstructive Surgery, The Catholic University of Korea, 327 Sosa-ro, Wonmi-gu, Bucheon 14647, South Korea. E-mail: joony@catholic.ac.kr

How to cite this article: Jun YJ. Comment on "Multipotency and secretome: the mechanisms behind the regenerative potential of adipose-derived stem cells". Plast Aesthet Res 2017;4:104-5.

Article history: Received: 28-02-2017 Accepted: 07-04-2017 Published: 27-06-2017

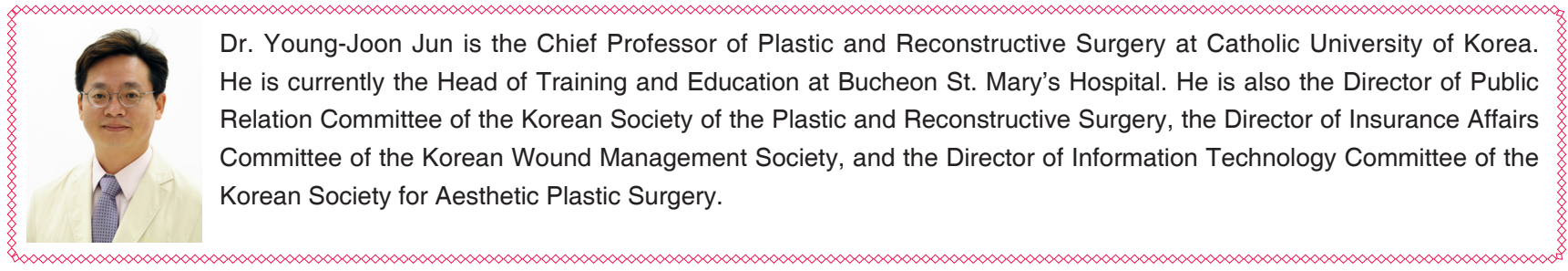

"Orgun D, Mizuno H. Multipotency and secretome: the mechanisms behind the regenerative potential of adipose-derived stem cells. Plast Aesthet Res 2017;4:32-40."

The application of stem cells technology to the intractable disease has emerged in the 21 st century. It has been applied to almost all areas of medicine, including cardiovascular, nervoulogic, hematologic, genetic, liver, endocrine and musculoskeletal diseases. In particular, stem cell mediated tissue regeneration has opened treatment options for previously-considered intractable diseases, with no other treatment alternatives.

Stem cells have the ability of self-replicating and differentiate into cells that make up various post- embryonicorgan systems. They play an important role in regeneration of organs and tissues throughout life. There are two basic types of stem cells: embryonic stem cells derived from blasto-cytes, and adult stem cells obtained from fully developed adult tissue or placenta. Embryonic stem cells proliferate with ease due to great self-replicating ability of their undifferentiated state. However, applying this knowledge raises ethical problems. Therefore, studies on adult stem cells are in progress.

Bone marrow-derived stem cells are one of bettercharacterized adult stem cells..$^{[1,2]}$ However, harvesting these bone marrow remains a challenge, and their isolation and yield ability is relatively low. For sufficient amounts of clinical use, multiple samples are required. Therefore, researchers have begun to explore new alternative sources of stem cells. Zuk et al. ${ }^{[3]}$ reported 
multi-lineage cells isolated from adipose tissues called stromal vascular fractions, which are assumed to be stem cells and named the cells "processed lipoaspirate." Lately, these "processed lipoaspirate" cells have come to be called adipose tissue-derived stromal cells, or adipose tissue-derived stem cells (ASCs). ${ }^{[4,5]}$ These cells, after being extracted and separated from adipose tissue, show stable growth and proliferation in culture environments, and have the capability of differentiating into various cell types, just like marrow stem cells. ${ }^{[6]}$

The authors reviewed 118 articles regarding ASCs using PubMed and Cochrane databases. They summarized: (1) immunophenotypic properties; (2) cellyield; (3) angiogenic effect; (4) effects on wound healing; and (5) immune modulation effect of ASCs. They raised a question of whether stem cell function alone or via a paracrine effect. Jun et al. ${ }^{[6]}$ reported that the effects of ASCs on neuronal regeneration might be caused by both the stem-cell itself, and a paracrine effect. The ability of mesenchymal stem cells to differentiate has been also reported to vary according to the tissue of origin, or the donor's age. ${ }^{[7]}$ However, the theory that the origin of the fat extract, gender, or age of the donor may affect the characteristic of differentiation is not yet supported by sufficient data.

In the authors' paper, ASCs have the ability to differentiate into several cell lineages, improve wound healing, and promote angiogenesis. I believe this study will be used to establish better applications of ASC therapy in the future.

\section{Authors' contributions}

Y.J. Jun contributed solely to the paper.
Financial support and sponsorship

None.

\section{Conflicts of interest}

There are no conflicts of interest.

\section{Patient consent}

Not applicable.

\section{Ethics approval}

Not applicable.

\section{REFERENCES}

1. Owen M. Marrow stromal stem cells. J Cell Sci Suppl 1988;10:63-76.

2. Bianco P, Gehron Robey P. Marrow stromal stem cells. J Clin Invest 2000;105:1663-8.

3. Zuk PA, Zhu M, Mizuno H, Huang J, Futrell JW, Katz AJ, Benhaim P, Lorenz HP, Hedrick MH. Multilineage cells from human adipose tissue: implications for cell-based therapies. Tissue Eng 2001;7:21128.

4. Hattori H, Sato M, Masuoka K, Ishihara M, Kikuchi T, Matsui T, Takase B, Ishizuka T, Kikuchi M, Fujikawa K, Ishihara M. Osteogenic potential of human adipose tissue-derived stromal cells as an alternative stem cell source. Cells Tissues Organs 2004;178:2-12.

5. Rodriguez AM, Elabd C, Delteil F, Astier J, Vernochet C, Saint-Marc P, Guesnet J, Guezennec A, Amri EZ, Dani C, Ailhaud G. Adipocyte differentiation of multipotent cells established from human adipose tissue. Biochem Biophys Res Commun 2004;315:255-63.

6. Jun YJ, Rhie JW, Choi YS, Kim YJ, Kim SE, Lee JI, Han KT. The effects of adipose derived stem cells on neurogenic differentiation and induction of nerve regeneration. J Korean Soc Plast Reconstr Surg 2006;33:205-12.

7. Lei H, Yu B, Huang Z, Yang X, Liu Z, Mao X, Tian G, He J, Han G, Chen H, Mao Q, Chen D. Comparative analysis of mesenchymal stem cells fromadult mouse adipose, muscle, and fetal muscle. Mol Biol Rep 2013;40:885-92. 